\title{
A Sacramental Wordplay: An Investigation of Pun Translatability in the Two English Translations of the Quran
}

\author{
Hossein Vahid Dastjerdi (Corresponding author) \\ Associate Professor \\ Faculty of foreign languages, University of Isfahan \\ Isfahan, Iran \\ Tel: 98-311-793-2111_E-mail: h_vahid@yahoo.com \\ Elaheh Jamshidian \\ M.A. Student \\ Faculty of foreign languages, University of Isfahan \\ Isfahan, Iran \\ E-mail: Jamshidian_elaheh@yahoo.com
}

\begin{abstract}
The present study aimed at examining a frequently-occurring element of the unique style of the Quran, i.e. puns. Adopting pun translation strategies outlined in Delabastita (2004) as a basis of measurement, the Quran and its two English renderings are hence analyzed to explore what strategies are applied by the translators on the one hand, and to discover the extent of (un)translatability of puns of the Qur'an, on the other hand. The results of the study revealed how feasible the strategies proposed by Delabastita (2004) in his theoretical framework are in terms of the (un)translatability of puns in the case of the Quran. The findings of the study will hopefully pave the way for further investigations on the translatability of different issues in Muslims' Holy Scripture. Also, the findings can be reconfirmed in future studies on other sacred books towards a possible generalization.
\end{abstract}

Keywords: The Quran, Pun, Translatability, Untranslatability, Translation strategy

\section{Introduction}

\subsection{The Quran}

The chanting of and listening to the beautiful verses of Allah, the Exalted, have remained delightful and enjoyable for over fourteen centuries, stimulating the soul and the heart of people of different languages and cultures. This uplift and enchantment is not limited just to the Arabs but it goes beyond geographical boundaries, race, nationality and culture, and is independent of time.

The Quran is the masterpiece of Arabic language from many standpoints such as linguistics and stylistics. The vocabulary, style, eloquence, effectiveness, and the rich poetic rhythm of this masterpiece, which lead to its linguistic and stylistic uniqueness, are the miracles of a Miracle, i.e. the Quran. As Arberry (1998) in the introduction of his book the Koran interpreted states, the Quran "is neither poetry nor prose but a unique fusion of both" (p. x). He believes that the rhetoric and rhythm of the Koran are so distinctive, powerful and emotive that any translation seems to be just a poor copy of the glorious original.

\subsubsection{The Quran, a unique genre}

As Mir (2000) states, what makes the literary repertoire of the Quran rich is its masterful use of language on the level of words and phrases. He adds, the all-pervading rhythm along with the rhymed prose create, in many verses, a spellbinding effect for those who can read the Quran in Arabic that is impossible to reproduce.

This is well reflected in Arberry's (1998) words below:

In making the present attempt to improve on the performance of my predecessors, and to produce something which might be accepted as echoing however faintly the sublime rhetoric of the Arabic Koran, I have been at pains to study the intricate and richly varied rhythms which - apart from the 
message itself - constitute the Quran's undeniable claim to rank amongst the greatest literary masterpieces of mankind (p.x).

According to Hitti (1970), "The style of the Koran is Gods' style. It is different, incomparable and inimitable. This is basically what constitutes to the "miraculous character' (ijaz) of the Koran. Of all miracles, it is the greatest" (para. 8). The Quran's unique genre is realized through two inseparable elements; rhetorical and cohesive elements. Rhetoric, the basis of the present study, is the use of language to please or persuade. Aristotle (1954) defines, Rhetoric "as the faculty of observing in any given case the available means of persuasion" (p. 5). The term would more appropriately be defined as the conveyance of meaning in the best of verbal forms.

From the literary point of view, the Quran's miraculous eloquence gives it the depth and the richness of meaning. Its creative and artistically rich style is only one element on which its eloquence is based. In his book, The Construction of the Bible and the Qur'an, Arbuthnot (1985) states:

"From the literary point of view, the Koran is regarded as a specimen of the purest Arabic, written on half poetry and half prose. It has been said that in some cases grammarians have adopted their rules to agree with certain phrases and expressions used in it, and that though several attempts have been made to produce a work equal to it as far elegant writing is concerned, none has as yet succeeded" (p. 245).

\subsubsection{Legitimacy of the Quran translation}

When it comes to the translation of the Quran, the question of its translatability is raised. Indeed, on the notion of untranslatability, Catford (1965) affirms that failure to find a target language equivalent is due entirely to the differences between the source language and target language. There are many debates on the translatability or untranslatability of the Quran which would be discussed under the following headings.

The proponents of absolute untranslatability of the Quran find their support in the sūrā Yūsuf (Josef): "we have sent down as an Arabic Quran"(verse. 2). They believe that translating Quran is illegitimate. "If men and jinn banded together to produce the like of this Quran, they would never produce its like, not though they backed one another" (Sūrā Al-Isra',The Night Journey, verse, 88). Through verses like this, the purity of the Quran's explanation and the eloquence of its expression, the comprehensiveness of its meanings, and the sublimity and sweetness of its styles are shown ("The way to truth", 2000). These together constitute one of the most brilliant aspects of the Quran's miraculousness- inimitability.

Regarding the untranslatability of the Quran, it is believed that the form and content, making the rhythm of the text, are linked in the sacred words to the extent that there is no way to render this relationship through another language, no matter how good the translation may be (Girard, 2007). The text of the Quran is so inimitable in its meanings, structures, rhetoric, and rhyme that it seems "any translation of the Quran immediately ceases to be the literal word of Allah, and hence cannot be equated with the Quran in its original Arabic form. In fact, each of the translations is actually an interpretation which has been translated" ('the Nobel Quran, 2009, para.5).

\subsubsection{Translatability of the Quran}

Translatability is defined as "a relative notion that has to do with the extent to which, despite obvious differences in linguistic structure (grammar, vocabulary, etc.), meaning can still be adequately expressed across languages" (Hatim and Munday, 2004, p. 15). On the basis of the above definition, considering all the linguistic and extra linguistic factors, it is possible to re-contextualize a text in TL (Wilss, 1982). "The translatability of a text is thus guaranteed by the existence of universal categories in syntax, semantics, and the (natural) logic of experience" (p. 42).

The opponents of the illegitimacy of the Quran translation believe that "it is legitimate to translate all verses of the Quran to the foreign tongue" (Abu Hanifa cited in Baker and, Saldanha, 2008, p. 201). Their rationale is that we live in an era in which the wider demand for translations of the Quran, among Muslims and non-Muslims alike, has become far greater than at any time in the past, and thus, "non-Muslim audience in many different parts of the world turns to the Quran - almost always in translation - in the search for the bases of deeper mutual understanding" (Morris, 2000, p. 53).

\subsubsection{Puns, problem, and procedures}

There are many English versions of the Quran. Considering the literary value of the Quran, the translations have errors arising from the failure to capture stylistic, pragmatic and figurative aspects (Muhammed, 2007). What is unique about the Quran as a source text is the process of its translation, i.e. although the source text is one, there are significant differences between different translations as the result of different procedures employed by translators. Logically, most translations of the Quran are source-oriented. In other words, satisfying the target audience is not 
generally favored, for the reason that it is the word of God. The extensive use of notes and lengthy introduction at the beginning of each translation prove this fact. Since the translations subtly change the meaning, they are often called interpretation (Baker and Saldanha, 2008).

The present study has gone through the investigation of one of the rhetorical devices not studied enough, i.e. pun in the Quran, from the point of view of translation. This study tries to find and classify different kinds of puns in the Quran and to explore the problematic areas in translating them. The study cannot be claimed to be a thorough one since there is no complete source containing all the puns in the Quran. Unfortunately, in each related reference book just a small portion is allocated to the puns. Although pun is one small part of the unique style of the Quran, it is employed in a very elegant way to foreground the meaning and draw the attention of the audience. Thus, the investigation of translatability of this rhetorical device in such a sacred text and the challenge of translators to preserve it as well as the message in their English renderings would be of significance. Digging out the strategies employed by the two translators, i.e. Arberry (1998) and Pickthall (2001) in tackling the puns in the Quran would be another outstanding part of this study.

The analysis of the feasibility of the procedures would also be useful for evaluating different translations of the Quran in order to seek the reasons for differences among them and to assess the success of translators in preserving the puns. Although the traditional attitude of untranslatability of puns has led to a lack of significant investigation into them, this phonoaesthetic component of sensitive texts like the Quran should not be overlooked in the task of translation.

\subsection{Definitions and terminology}

Pun: As defined by Newmark (1988), one makes a pun by using a word, or two words with the same sound ('piece'/'peace'), or a group of words with the same sound (personne alitee/ personnalite) in their two possible senses, usually for the purpose of arousing laughter or amusement, and sometimes also to concentrate meaning" (p. 217).

\subsubsection{Pun categorization in Arabic (SL)}

Puns in Arabic language are divided into the puns "لفظي" and "معنوي" and their subcategories (Alsafadi, 1987). As a matter of fact, different categorizations have been made by different rhetoricians as there is no unanimous agreement on the different kinds of puns in the rhetorical works. Based on generality, an eclectic categorization is made as follows:

According to Alsafadi (1987), the pun called "لفظي " is defined as "the similar words which are pronounced the same but written differently" (p.71). This kind of pun is divided into the subcategories which are as follows:

تام: In this kind of pun, the words are exactly of the same forms and spellings, but of different meanings (Alsafadi,1987). The examples are (i.e. Judgment Day) and (i.e. time). Being of the same characteristics, homonymy is this pun's counterpart in English.

ناقص: According to Alsafadi (1987), the term is used when the two similar words are different in the number of letters, i.e. extra letters are added to one of the two words . These extra letters can be in the beginning, middle, or at the end like البحر//البر. The addition of the extra letters to the beginning of one of the two words makes another kind

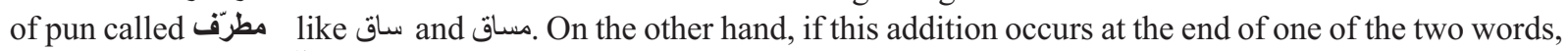

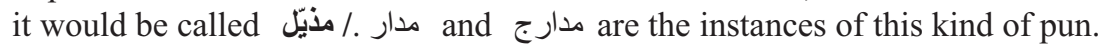

مضارع: The term is used when the similar words are different just in one letter in each word. This kind of pun خير and خيل. On the basis of similarity and closeness of sounds, paronomy can be equated with this kind of pun.

لاحق: In this kind of pun, the similar words are different not only in one letter in each word but also in their place of

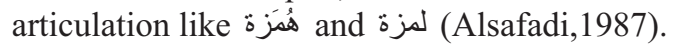

محرّت As Alsafadi (1987) states, in this kind of pun, the difference of the similar words arises from the difference in the diacritics of the two words like البُرِد and añ

ن ' مصحّف '/n/ (Alsafadi,1987).

قلب: In this kind of pun, according to Khaghani (1997), the reversion of the letters happens either in the whole or

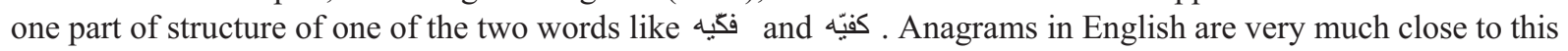
kind of Pun in Arabic. 
مستوى: This kind of pun is found in the phrases or sentences which are read the same, backwards or forwards, i.e. they are read from the end to the beginning as if they are being read from the beginning to the end, (Al-Shirazi,1997) like (Palindrome, one type of English puns, is regarded as equivalent to this Arabic pun. The example is 'live not on evil'

اشتقاق : In this kind of pun, the two different words are puns provided that they are derived from the same root (Khaghani,1997), like مسلمون and Polyptoton, one type of homophonic puns, is the English equivalent of this pun.

شبه اشتقاق and قالين In this kind of pun, similar words are derived from different roots (Khaghani,1997), like قالين.

As the second category of puns called "معنوي" is rejected as a category of puns by many scholars such as Khaghani (1997) and Syūtî (1984), this study will lay its focus on analyzing only the first type.

\subsubsection{Pun categorization in English (TL)}

As far as the present study is concerned, the puns existing in Arabic are found in English as well. However, they come under the general term 'pun'. In fact, the vast realm of puns has lamed the efforts to categorize them. "Scholars have sought to define and classify puns, but the results have never met with much success" (Culler, 1988, p.4). However, based on their formal identity, puns are divided into different categories, some of which are as follows:

1. Homography: This kind of pun refers to the words (i.e. lexemes) which are of the same spelling but of different meaning (Crystala, 2003). Homography is illustrated from such pairs as 'wind' (blowing) and 'wind' (a clock).

2. Homonymy: This kind of pun refers to lexical items which are of the same form but of different meaning. 'Bear' (animal, carry) is an example of homonyms (Crystala, 2003).

3. Homophony: This kind of pun refers to lexemes which are of the same pronunciation but of different spelling and meaning. The words 'throw' and 'through' are the examples (Crystala, 2003).

4. Paronomy: Phonological similarity of the words and the morphological structure is the characteristic of paronymic puns. The examples are the words 'faith' and 'face' are different from each other only in their last phoneme (Marjamäki, 2001).

5. Palindrome: Palindromes are spelled the same, backwards or forwards, such as 'mom', 'race car', or 'defied' (Puns and Wordplay, 2001).

\section{Background of the Study}

\subsection{The Quran}

The Quran has been studied from different standpoints including linguistics and stylistics. In this regard, the following studies are worth mentioning:

Zolfaqari (2006) examines the reflection of the Quran in Persian proverbs. He shows the reflection of signs in Persian proverbs in one of the underlying forms: 1) application of the original sign, 2) application of the content of sign, 3) using the words compositions, terms or Quranic interpretation or a part of the sign, 4) allusion of Quranic stories. His study reveals that out of 3000 unrepeated published Persian proverbs, the direct effect of about 900 signs of Quran on 3 percents of these proverbs is obvious, and that Most of the effective signs on proverbs are among the famous signs or in Sūrās of the 30th part of Qur'an.

Muhammed (2007) focuses on the errors which the translators capture in translating the euphemistic expressions in the Quran. His aim in the study is twofold, i.e. to expose those translators who sacrifice euphemism at the expense of the original meaning and vice versa on the one hand, and to show to what extent these wrong translations of euphemisms affect the understanding of the meaning on the other hand. He concludes the best translators are those who mention the euphemism followed by a paraphrase to make it easy for the target receivers to understand what is intended to be relayed to their language.

Abdelwali (2007) studies the challenges that Quranic translators encounter at the lexical, structural /stylistic, and rhetorical levels. His survey of existing English versions of the Quran shows that the most a translator aims at is the communication of the message without considering the idiosyncrasies and prototypical features of the Quranic discourse. His conclusion is that the versatility of Quranic lexemes and styles were not captured in most of the English versions of the Quran.

In his paper, Elhindi (2008) proposes a cognitive approach employing the principles of the conceptual metaphor theory - proposed by Lakoff and Johnson as a framework to categorize and explain the significance of metaphors in the Quran. His paper focuses on spatial and temporal Quranic metaphors and investigates how they are used to 
help enhance the interpretation of specific concepts. Moreover, the difficulty of translating Arabic metaphors into English are also addressed in his study. He shows that how some of the English translations of metaphors fail to capture some of the subtle meanings rendered by the Arabic versions.

Representing a new development in the study of Quranic text, El-Awa (2009) tackles the issue of Quranic text structure by fusing the fields of linguistics and Quranic studies. According to her, the Quran contains many long Sūrās covering diverse topics but with no apparent common context within which such variety can be explained. She proposes a new explanation of Quranic text structure, arguing that the long Sūrās have structures that are explicable within a framework for the mechanisms of human verbal communication. Through a systematic step-by-step analysis of the cognitive process involved in verbal communication and comprehension of text, she provides interesting and useful insights into the methods of analyses, mechanisms and dynamics of the Quranic text structure.

\subsection{Pun}

Delabastita (1996) asserts that puns can be thought of as contrasting "linguistic structures with different meanings on the basis of their formal similarity" (p.128). He defines pun as "a general name for the various textual phenomena in which structural features of the language used are exploited in order to bring about a communicatively significant confrontation of two linguistic structures with more or less similar forms and with more or less different meanings (p.31).

Nida (1993) describes pun as follows: "Playing on the meaning and formal resemblance of words (punning) is a universal phenomenon, and in some languages this rhetorical device is extensively encouraged and practiced" (p.87). Also, Culler (1988) notes, "puns present a model of language as phonemes or letters combining in various ways to evoke prior meaning and to produce effects of meaning" (p.14). To put another way, similarity of sound passes into or gives rise to semantic relationships.

\subsubsection{Pun in the Quran}

One of the stages in the study of the miracles of the Quran is to examine it with a scientific perception. In this stage, sciences such as linguistics and rhetorics investigate the miracles in the Quran. One of the subcategories of rhetorics is punning. In rhetorics, although the focus is on the meaning rather than form, the beauty of form charming to ears of the readers and hearers would help the understanding of meaning.

There are novel and wonderful cases of puns in the Quran. Considering the message of the holy language, the unique characteristic of these puns is their application in the most appropriate parts of the verses. This uniqueness has brought forth a sublime reconciliation between form and content. Thus, through this eloquent, rhetorical, and miraculous language, the meaning of the verses penetrates into people's souls and hearts. Actually, the wordplay in the Quran with its persuasive quality makes the audience much more eager to listen to the Quran and to read it. The question might be raised as to how this is achieved? Indeed, it is the symmetry between words when they are, as Crisafulli (1996) states, "analogous in form but dissimilar in meaning" (p.261). Puns in the Quran include intervals, the rhythmic words at the end of the verses. This process resembles saj' in prose and rhyme in poetry. A vast part in the Qur'an has been allocated to this domain.

\subsection{Translating puns}

Newmark (1988) refers to the translation of puns as of "marginal importance and of irresistible interest" (p. 217). On the difficulty of translating puns in poetry, he maintains that "puns made by punning poets are most difficult to translate, since they are limited by metre. Often the pun simply has to be sacrificed" (p. 217). Based on the reason that puns depend on the structural features of a language, and that different languages have different structures, some scholars believe that the task of translating them may be considered to be an impossible one.Girard (2007) argues that "puns are translatable but involve the inevitable loss of information not only in the form or code (signifier) but also in the content or message (signified)" (para.3).

Many studies have been done regarding pun, pun (un)translatability, pun translation and the strategies on their translations. The two important schools, post structuralism and feminism, use pun as an instrument in their efforts to deconstruct mainstream language and ideology. "The most intractable translation problem, wordplay, is a major concern of post-structuralism, as well as a prominent feature of its discursive method" (Davis, 1997, p. 24). In feminist literature, pun was a widespread tool used to deconstruct patriarchal ideologies, and to demonstrate women's abilities.

In contrast to Post-structuralists that see pun as a resisting definition, classification and especially translation, translation scholars see pun translation "as a cline, i.e. a relative rather than an absolute category" (Delabastita, 1994, p. 226). 
Modrea (2006) emphasizes the difficulty in translating feminist puns due to their language and culture-specific references. As he notes, the translator, thus, would have to creatively find or invent puns reflecting both the insistence on the female and deconstructing the elevated status of the male.

In the paper, "The study of pun in English translations of Sa'di's the Bustan", Eslami Rasekh and Ordudary (in press) discuss about the procedures employed in rendering puns, and consistency of the translator in the choice of strategies viewed as the most effective. They studied Sa'di's the Bustan and its English translation by Clarke (1976) based on Delabastita's model for puns translation. Their conclusion was that (un)translatability of any aesthetic element of a literary work in general and pun in particular majorly depended on the level of similarity between linguistic systems involved in the process of translation, namely SL and TL. They showed that zero translation/omission is the most frequently strategy employed by the translator.

Ma azallahi (2007) in "An Investigation of Pun Translatability in the English translations of Hafiz Poetry" examined the translatability of pun in poetry translation and the translation strategies employed by English translators to deal with different types of puns. To do so, she took the selected couplets of Hafiz containing puns compatible to Delabastita's (1996) classification and the two English translations of Clark (1905) and McCarthy (2006). Ma'azallahi systematically showed that the feasibility of the theoretical framework proposed by Delabastita (2004) concerned with translating puns, seemed to be justified, and that his strategies would be applicable in the course of translating pun in poetry. Therefore, the notion of translatability of puns seems to be possible according to her research.

In "Problems of Rendering Linguistic Devices in Rumi's poetry", Ordudary (2008) approaches pun translatability and the loss in English translation of Rumi poetry. He reaches the conclusion that in pun translation, omission of the image through resorting to a mere literal translation leaves the TT reader unaware of the concepts underlying the original text. Moreover, he suggests a strategy named 'couplet' - the combination of two procedures: literal translation and footnote - as the most effective procedure in translating puns.

\subsubsection{Strategies of pun translation}

A variety of strategies are employed by the translators once faced puns in the source text. In his article, Hwang (1980) offers three strategies which are providing footnotes, writing explanation into the pun, and resorting to invention to preserve the original flavor of the pun. Regarding the strategies, Huang (2001) notes that "in translating a pun, the first consideration should be to try to come up with something like an equivalent to the original in sound and meaning. The second priority is creative transposition, and the last is to footnote which at least is better than a complete omission, but of little value in translating puns" (p.919).

Delabsitata (2004) offers an elaborate list of strategies in translating puns. According to these strategies, the translator translates the source text (TT) pun to:

1) a pun in the target text (TT) which doesn't necessarily have the same properties of the ST pun.

2) non-pun in which ST pun turns out to be a phrase in the TT; may both senses of the pun are salvaged or just one of the senses is conveyed.

3) rhetorical related devices in which the pun is replaced with a different rhetorical device, such as repetition, alliteration or rhyme.

4) zero, in which the pun is simply omitted together with its context.

5) ST pun which is reproduced without any changes to its form and semantic content.

Sometimes, the translators can produce the aesthetic effect vice versa by translating a:

6) non-pun to pun, in which the translator introduces a pun in the TT which doesn't exist in the ST.

7) zero to pun in which a new pun is added without any apparent justification in the ST for the sake of beautification.

8) using editorial techniques containing footnotes explaining the differences between the two languages and the possible solutions.

For the reason of their practicality, Delabstita's (2004) strategies have been chosen as the framework in many studies including the present one.

Considering the Quran and its puns, the present study would examine pun translatability in the two English renderings of the Quran to see how the translators have dealt with this phenomenal rhetorical device in their renderings. 


\section{Method}

\subsection{Design of the study}

The focus here was a descriptive study in which different types of puns chosen randomly from 80 verses in 40 Sūrās in the Quran and its two English translations by Pickthall (2001) and Arberry (1998) were investigated based on Delabastita's (2004) model for pun translation. Among many translations of the Quran, the above mentioned translations were selected on the ground that the renderings by these two translators have been claimed by many to be more comprehensive, faithful, and literary than others, although translating the word of God bears inevitable loss.

\subsection{Procedures}

The procedures used to conduct the present study were as follows:

1. Studying the original text and locating the items under study (i.e. puns).

2. Identifying the puns which are randomly chosen from 80 verses in 40 Sūrās (chapters) in the Quran and their equivalents in the two English renderings

3. Reading the translations and comparing the given translated items not only with one another, but also with the original text.

4. Determining the strategies applied by the English translators in rendering the puns of the source text.

5. Concluding from the data elicited in the above manner to determine the most frequently used strategies and to decide on the (un)translatability of the Quranic puns based on the applied strategies.

\section{Data Analysis and Discussion}

Based on Delabstita's (2004) framework, the extracted data in the present study were classified according to the categorizations in the source text and the two English renderings. Then, the strategies applied by the two translators in each case were explored thoroughly. It is to be mentioned that for the limitation of space and not being able to show all the instances of puns detected in the Quran, the study has restricted the discussion to the more prominent instances and checked the selected renderings against them to figure out how far (if at all) various kinds of puns are (un)translatable. The complete data along with their categorizations are presented in the appendix tables.

Consider the following exemplar verses and the two renderings:

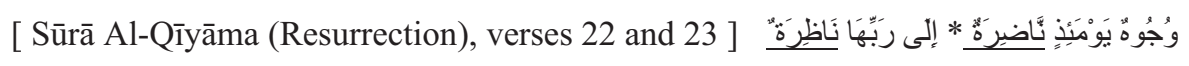

Pickthall: That day will faces be resplendent, Looking toward their Lord;

Arberry: Upon that day faces shall be radiant, gazing upon their Lord

The above two verses show the poetic value of the Qur'an. The two ending words, besides being rhymed, are the instances of the pun called "لفظي". Apparently, there is no equivalent for such kind of pun in the target language. Since the translators have translated it literally, the aesthetic value of the verse is lost. Thus, 'pun to non-pun' is the strategy used.

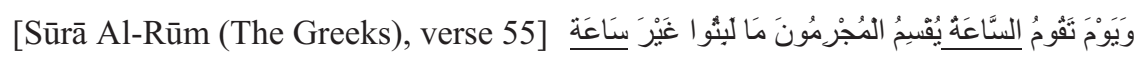
Pickthall: And on the day when the Hour riseth the guilty will vow that they did tarry but an hour - thus were they ever deceived.

Arberry: Upon the day when the $\underline{\text { Hour }}$ is come, the sinners shall swear they have not tarried above an $\underline{\text { hour; }}$

What attracts the attention is the autonomous creation of pun in the target renderings. In fact, the above verse verifies the knowledge of the two translators of the wordplay in the Quran. The pun used in the source verse is تنام. In the verse, the first ' hour' means 'the Day of Judgment'. The translators have distinguished it from the second 'hour' meaning 'time' by the use of capital letter. Translating 'pun to pun', both translators have been successful in conveying both sense and form.

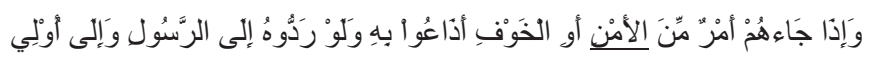

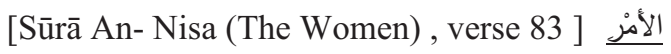

Pickthall: and if any tidings, whether of safety or fear, come unto them, they noise it abroad, whereas if they had referred it to the messenger and to such of them as are in authority, 
Arberry: When there comes to them a matter, be it of security or fear, they broadcast it if they have referred it to the Messenger and to those in authority among them,

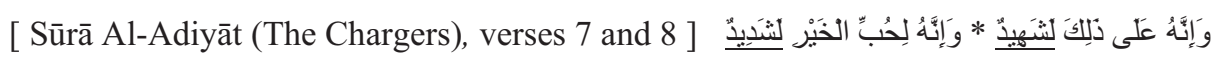

Pickthall: And lo! He is a witness unto that; And lo! in the love of wealth he is violent

Arberry: and surely he is a witness against that! Surely he is passionate in his love for good things.

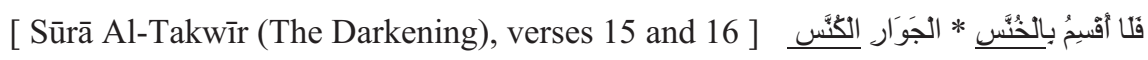

Pickthall: oh, but I call to witness the planets, the stars which rise and set,

Arberry: No! I swear by the slinkers (stars that recede), the runners, the sinkers

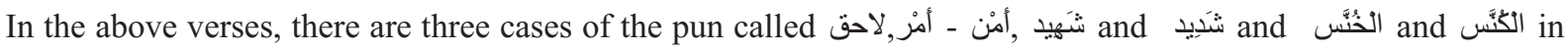
which the two words are different just in one letter and that the places of articulation are much different from each other. As the purpose of this kind of pun is to foreground the meaning by the use of sounds, it is totally lost in the two English translations. But, the two translators have tried to compensate the loss by related rhetorical devices. In the first case, the two rhymed words are seen. Alliteration is what the first translator has used to recapture the effect in the second case. Finally, in the third case which is of prominence, the second translator has interestingly reproduced another pun in TT called "sound-based paronymy" (Delabastita, personal communication, February 5, 2010). He, thus, has compensated for the lost pun by another pun in the target text.

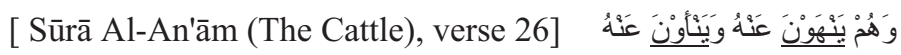

Pickthall : And they forbid (men) from it and $\underline{\text { avoid it, }}$

Arberry: And they forbid it, and keep afar from it,

As can be observed, the pun مضارع, underlined, is completely lost in the target text. The translators have transferred the sense but failed to create the aesthetic value of the pun. Indeed, there is no relationship between the target words, i.e. 'forbid' and 'avoid', 'forbid' and 'keep afar from'. Put it another way, the strategy employed is 'pun to non-pun'.

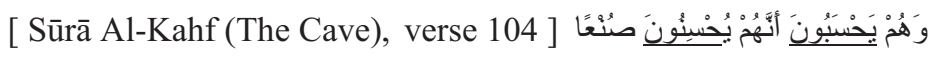

Pickthall: and yet they reckon that they do good work.

Arberry: while they think that they are working good deeds.

Here is a significant combination of the two puns محرف and مصحق /. The loss is unavoidable for the reason that there are no diacritics and also diacritical dots for letters in the target language. Thus, creating such puns has been impossible by the two translators. However, they have conveyed the sense of the verse. Therefore, the strategy would be translating 'pun to non-pun'.

[ Sūrā Al-Anbīyā' (The Prophets), verse 33] كلّ فِي فلكٍ

Pickthall: They float, each in an orbit.

Arberry: each swimming in a sky.

One of the miracles of the Quran is its mystical wordplay. Surprisingly, if the above two verses are read from the end to the beginning, there would be no change, as if they were being read from the beginning to the end. The above verse is an instance of the pun sستوى. In English, such a pun is called epalindrom which the two translators failed to reproduce in the target language. They have just conveyed the sense.

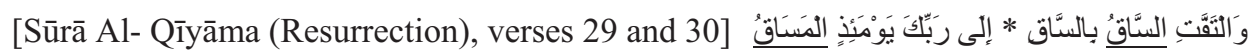

Pickthall: And agony is heaped on agony; Unto thy Lord that day will be the driving.

Arberry: and he thinks that it is the parting and leg is intertwined with leg, upon that day unto thy Lord shall be the driving

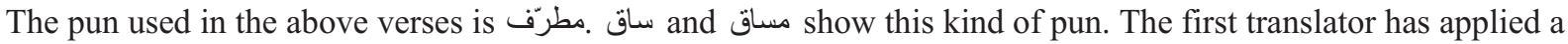
pragmatic translation overlooking the form. Thus the strategy used by him is 'zero translation'. The second translator has applied a literal translation conveying the sense, but failed to reproduce the pun in the target language. Therefore, the strategy used by him is translating 'pun to non-pun'.

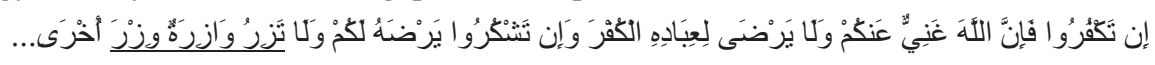

[ Sūrā Az-Zummar (The Companies), verse 7 ]

Pickthall: If ye are thankless, yet Allah is independent of you, though he is not pleased with thanklessness for his bondmen; and if ye are thankful he is pleased therewith for you. No laden soul will bear another's load... 
Arberry: If you are unthankful, God is independent of you yet He approves not unthankfulness in His servants, but if you are thankful, He will approve it in you and no soul laden bears the load of another...

In the above verse, the masterly mixture of the puns انتقاق and on the one hand and alliteration on the other, is among the rhetorical miracles of the Quran. In the pun انتقاق are somehow different in meaning. The two translators have managed to convey this kind of pun just in some cases. The reason lies in the distance between the two languages being of two different families. In the above instances, keeping the derivation has reproduced the alliteration in the two renderings as well. Thus the translators have succeeded in reproducing the effect in the target language.

\section{Conclusion}

What seems obvious about the translation of all texts, especially literary and sacred ones, is the fact that the message can be conveyed while the form of message may differ in the source and target languages.

Although puns are believed to be one of the most daunting problems in the area of translation, Newmark (1988) believes that they are "most easily translated if they are based on Graeco-latinisms that have near-equivalents in the source and target languages, particularly if they simply contrast the material and the figurative sense of the word" (p. 217). In other words, the similarity between the source text and target text decreases the difficulty of translating puns. In the case of the Quran, it can be argued, based on the examples maintained above, that the translators failed to convey the aesthetic value of the original. The reason lies in the above-mentioned statement of Newmark (1988). In fact, Arabic and English are two languages of very different families.

Regarding the aesthetic value of the Quran created by the use of puns, much is lost in the translations. One of the most important factors in making the Quran untranslatable is its use of the untranslatable in its text. That is what makes the Quran unique. In some cases, two or three puns are mixed in such an elegant way that no translator can reproduce them in the target language. Indeed, the symmetry between words when they are, as Crisafulli (1996) states, analogous in form but dissimilar in meaning (p.261), makes the Quran much more beautiful and urges the eagerness in the readers and listeners. Conveying only the sense has deprived the readers and listeners of the target language of such a Godly endowment in most cases.

As different kinds of puns have been chosen on a random basis, Meccan and Medinan sūrās were both examined in the present study. The results showed that eight of all puns were found in eight sūrās which were Medinan. Interestingly, this shows the literary repertoire of Medinan sūrās as well as the Meccan ones.

Considering wordplay and the role of forms and sounds in creating the effect, on the basis of Delabastita's (2004) theoretical framework, in the cases of the puns مستوى, قلب , مصحف , محرف , لاحق , مضارع , مذيل, مطرف ,ناقص , and شبه انثتقاق 'pun to non-pun' translation was realized as the most frequent procedure employed by Pickthall (2001) and Arberry (1998) in the English renderings of the Quran. However, this procedure is by no means effective since, as far as this study is concerned, the form and sound play fundamental roles in each case and give rise to semantic interrelatedness. Also, since the translators should be faithful to the text of the Quran, 'pun to non-pun' strategy seems to be the last resort for them.

As mentioned before, in the case of the pun انتقاق|, due to the two words' derivation of the same root, reproducing it was possible in the target language, and the translators have conveyed it in the target language to some extent. However, the distance between the two languages on the one hand and fidelity to the content on the other, did not allow for the reproduction of the effect in the target text in most cases.

In some other cases, the two translators have tried to convey the aesthetic value by the use of 'compensation strategy'. In the case of the pun تام, both translators have been successful in rendering both the form and sense. Also, alliteration and rhyming as compensatory strategies were effective in reproducing the aesthetic effect in the target language.

Regarding these two great translators' work, what is clear is that they have been informed of the puns used in the Quran, but due to the reasons mentioned above, both have failed in recreating most of the cases in the target language. In fact, the reproduction of the effect and recreation of the puns by the translators of God's words in the target language is of weighty worth, because in almost all the cases, form of the words and sounds play an important key role in foregrounding the meaning, but the results obtained from the present study established the notion of untranslatability of puns in the two English translations of the Quran.

\section{References}

Abdelwali, M. (2007). The Loss in the Translation of the Qur'an. Translation Journal, 11(2). [Online] Available: http://accurapid.com/journal/40quran.htm (June 24, 2009).

Al-safadi, S. Kh. (1987). Jinan al-jinas (fi ilm al-badi). Lebenan: Dar al-Kutub. 
Al-Shirazi, M. (1997). Al-Balaqa: [Online] Available: http://www.alshirazi.com/compilations/lals/balagah/part3/3.htm (March 14, 2009).

Arberry, A. J. (1998). The Koran Interpreted: A Translation. London: Oxford University Press.

Arbuthnot, F. F. (1985). The Construction of the Bible and the Koran. London: Watts.

Aristotle. (1954). Rhetoric (W.R. Roberts, Trans.). [Online] Available: $\mathrm{http} / / /$ books.google.com/books?id=V_IMCohto0YC\&printsec=frontcover\&source=gbs_navlinks_s\#v=onepage $\& \mathrm{q}=\& \mathrm{f}=$ false (April 20, 2009).

As- Syūtī, J. A.R. (1984). Al-Itqan fi ulumul Qur'an (Haeri Qazvini, M. Trans.). 2. 88-89. Tehran: Amir Kabir Publication.

Baker,M, \& Saldanha, G. (2008). Routledge Encyclopedia of Translation Studies. [Online] Available: http://books.google.com/books?id=T8Mt8ObEBOQC\&printsec=frontcover\&dq=Routledge+Encyclopedia + of $+\mathrm{T}$ ranslation+Studies (June 24, 2009).

Catford, J.C. (1965). A Linguistic Theory of Translation. Oxford: OUP.

Crisafulli, E. (1996). Dante's Puns in English and the question of compensation. In D. Delabastita (Ed.), The translation studies in intercultural communication 2 (2), special issue: Wordplay \& Translation (pp. 259-276). Manchester: St Jerome.

Crystala, D. (2003). A dictionary of linguistics \& phonetics. [Online] Available: $\mathrm{http} / /$ books.google.com/books?id=bSxjt 1 irqh $4 \mathrm{C} \&$ printsec $=$ frontcover $\& \mathrm{dq}=\mathrm{A}+$ dictionary + of + linguistics $+\% 26+$ phonetics (June 24, 2009).

Culler. J. (1988). On puns: The foundation of letters. Oxford: Blackwell.

Davis, K. (1997). Signature in Translation. In D. Delabastita (Ed.). Traductio: Essays on Punning and Translation (pp. 23-43). Manchester: St. Jerome.

Delabastita, D. (1994). Focus on the Pun: Wordplay as a Special Problem in Translation Studies. Target, 6(2), 223-243.

Delabastita, D. (Ed.). (1996). The Translator: Studies in intercultural communication 2 (2), Special Issue: Wordplay \& Translation. Manchester: St Jerome.

Delabastita, D. (2004). Wordplay a translation problem: a linguistic perspective. Uberstzung translation traduction, 1(1), 600-606. Berlin/New York: Walter de Gruyter.

El-Awa, S. M. (2009). Textual Relations in the Qur'an: Relevance, Coherence and Structure. [Online] Available: http://www.routledge.com/books/Textual-Relations-in-the-Quran-isbn9780415554206 (June 24, 2009).

Elhindi, Y. (2008). 'Metaphors in the Quran: Categories and Significance'. Papre presented at the sixth international conference on new directions in the humanities. Fatih University.15-18 July 2008. [Online] Available: http://h08.cgpublisher.com/proposals/381/index_html (June 24, 2009).

Eslami-Rasekh, A \& Ordudari, M. (in press). The study of pun in English translations of Sa'di's the Bustan. Translation Studies.

Girard, A. (2007). On the Relative (Un)translatability of Puns. [Online] Available: http://www.multilingualwebmaster.com/library/puns_translation.html (May 2, 2009).

Hatim, B \& Munday, J. (2004). Translation: An Advanced Resource Book. USA/ Canada: Routledge.

Hitti, P, K. (1970). The First Book. Aramco World, 21(6). [Online] Available: http://www.saudiaramcoworld.com/issue/197006/the.first.book.htm (June 26, 2009).

Huang, I. (2001). Puns. In S. Chan, D. E. Pollard (Eds.), An encyclopedia of translation (pp.918-924). [Online] Available:

http://books.google.com/books?id=4fWf1WlCStcC\&pg=PPA918\&vq=pun\&source=gbs_search_s\&cad=0 (May 2, 2009).

Hwang, W. M. (1980). Translating puns for the stage. Renditions, 16, pp.73-78. [Online] Available: http://www.renditions.org/renditions/magazine/14.html (May 2, 2009).

Khaqani, M. (1997). Jelvehayeh Balaghat dar Najulbalaqah, (in Persian). Tehran: Bonyad Nahjulbalaqa.

Ma'azallahi, P. (2007). An Investigation of Pun Translatability in the English translations of Hafiz Poetry. Unpublished master's thesis. Isfahan University. Isfahan, Iran.

Marjamäki, P. (2001). A study on language-bound humor and its translation. M.A. thesis, Department of English, Helsinki Faculty of Arts. 
Mir, M. (2000). The Qur'ān As Literature. Renaissance, 10(5). [Online] Available: http://www.islamic-awareness.org/Quran/Q_Studies/Mirliter.html (December 20, 2009).

Modrea, A. (2006). Ideology, Subversion and the Translator's Voice: A Comparative Analysis of the French \& English Translations of Guillermo Cabrera Infante's Tres tristes tigres. TRANS, 16 (9.4). [Online] Available: http://www.inst.at/trans/16Nr/09_4/modrea16.htm (April 30, 2009).

Morris. W. J. (2000). Qur'an Translation and the Challenge of Communication: Toward a 'Literal' (Study) Version of the Qur'an. Journal of Qur'anic Studies, 2, 53-68. [Online] Available: http://escholarship.bc.edu/james_morris/39/(March 26, 2009).

Muhammed, G. A. (2007). Errors in English Translations of Euphemism in the Holy Qur'an. Qur'anic Studies. [Online] Available: http://www.quranicstudies.com/articles/language-of-the-quran/ (June 24, 2009).

Newmark, P. (1988). A Textbook of Translation. Hertfordshire: Prentice Hall.

Nida, E. A. (1993). Language, Culture, and Translating. Shanghai: Shanghai Foreign Language Education Press.

Ordudari, M. (2008). Problems of Rendering Linguistic Devices in Rumi's poetry. Translation Journal, 12 (2). [Online] Available: http://accurapid.com/Journal/44rumi.htm (May 7, 2009).

Pickthall, M. M. (2001). The Meaning of the Glorious Qur'an. New York: TTQ, INC.

Pun and Wordplay. (2001). Palindromes. [Online] Available: http://www.bbc.co.uk/dna/h2g2/A592643 (June 24, 2009).

The Nobel Qur'an. (2009). Iqra. [Online] Available: http://www.iqra.se/quran/quran_al_kerim.php (April 15, 2009).

The way to truth. (2000). The Quran is the greatest of all the prophetic miracles. [Online] Available: http://www.thewaytotruth.org/theholyquran/propheticmiracles.html (June 22, 2009).

Wilss, W. (1982). Science of Translation: Problems and Methods. Tübingen:Narr.

Zolfaqari, H. (2006). The Reflection of Holy Quran in Persian Proverbs. Journal of the Iranian Association of Arabic Language and Literature, 2(5), 109-136.

\section{Appendix}

Number of puns in the Quranic verses:

\begin{tabular}{|c|c|c|}
\hline جناس (pun) & سورة)(Sūrā) & آيه (verse) \\
\hline لفظي & $\begin{array}{c}\text { Al-Qīyāma (Resurrection) } \\
\text { Al-Fath }\end{array}$ & $\begin{array}{l}22 \text { and } 23 \\
25 \text { and } 26\end{array}$ \\
\hline تام & Al-Rūm (The Greeks) & 55 \\
\hline مضارع & $\begin{array}{c}\text { An-Nisā (The Women) } \\
\text { Al-Ana'ām (The Cattle) } \\
\text { Al-Tawba (Repentance) } \\
\text { AN-Nazia'āt (The Pluckers) } \\
\text { Al-Mursalāt (The loosed ones) } \\
\text { An-Najm (The star) } \\
\text { At-Takwīr (The Darkening) } \\
\text { Al-Alaq (The blood Clot) }\end{array}$ & $\begin{array}{c}12 \\
26 \\
101 \\
6 \text { and } 7 \\
20 \text { and } 21 \\
48 \\
15 \text { and } 16 \\
1 \text { and } 2\end{array}$ \\
\hline ناقص & $\begin{array}{c}\text { Al-Ana'ām (The Cattle) } \\
\text { Ibrāhīm (Abraham) } \\
\text { Al-Qalam (The Pen) } \\
\text { Az-Zumar (The Companies) }\end{array}$ & $\begin{array}{c}97 \\
41 \\
19 \\
7\end{array}$ \\
\hline مذيّل & $\begin{array}{c}\text { Al-Rūm (The Greeks) } \\
\text { Al-Jathia (The Hobbling) }\end{array}$ & $\begin{array}{l}33 \\
27 \\
\end{array}$ \\
\hline مطرّف & $\begin{array}{c}\text { An-Nās (The men) } \\
\text { Al-Qisas (The Story) } \\
\text { Al-Arāf (The Battlements) } \\
\text { Al-Adīyāt (The Chargers) }\end{array}$ & $\begin{array}{c}3 \text { and } 4 \\
45 \\
86 \\
11\end{array}$ \\
\hline
\end{tabular}




\begin{tabular}{|c|c|c|}
\hline & $\begin{array}{c}\text { An-Nisā (The Women) } \\
\text { AL-Muzzammil (The Enwrapped) } \\
\text { Saba' (Sheba) } \\
\text { Al- Qīyāma (Resurrection) }\end{array}$ & $\begin{array}{c}143 \\
5 \text { and } 6 \\
37 \\
29 \text { and } 30\end{array}$ \\
\hline لاحق & $\begin{array}{c}\text { Al-Humaza (The Backbiter) } \\
\text { Al-Adīyāt (The Chargers) } \\
\text { Al-Anbīyā' (The Prophets) } \\
\text { An-Nisā (The Women) } \\
\text { Al-Qāfir (The Forgiver) } \\
\text { Al-Ana'ām (The Cattle) } \\
\text { Maryam (Mary) } \\
\text { Al-Arāf(The Battlements) }\end{array}$ & $\begin{array}{c}1 \text { and } 2 \\
7 \text { and } 8 \\
39 \text { and } 40 \\
52 \text { and } 53 \\
75 \\
95 \\
52 \text { and } 53 \\
95\end{array}$ \\
\hline محرّن & $\begin{array}{c}\text { An-Nisā (The Women) } \\
\text { Al-Arāf (The Battlements) } \\
\text { Al-Baqara (The Cow) } \\
\text { As-Sāffăt (The Rangers) } \\
\text { Al-Kahf (The Cave) }\end{array}$ & $\begin{array}{c}136 \\
197 \text { and } 198 \\
279 \\
72 \text { and } 73 \\
104\end{array}$ \\
\hline قلب & $\begin{array}{r}\text { Tā-Hā (Ta-Ha) } \\
\text { An-Nisā (The Women) } \\
\text { Al- Mā'eda (The Table) }\end{array}$ & $\begin{array}{l}94 \\
11 \\
27\end{array}$ \\
\hline مصحقف & $\begin{array}{c}\text { Al-šuarā (The Poets) } \\
\text { Al-Kahf (The Cave) } \\
\text { Al-Arāf (The Battlements) }\end{array}$ & $\begin{array}{c}79 \text { and } 80 \\
104 \\
197 \text { and } 198\end{array}$ \\
\hline اشتقاق & $\begin{array}{c}\text { An-Nisā (The Women) } \\
\text { Al-Arāf (The Battlements) } \\
\text { Al-Anfāl (The Spoils of War) } \\
\text { Al-Wāqi'a (The Terror) } \\
\text { Al-Rūm (The Greeks) } \\
\text { AR-Rahmān (The-All-Merciful) } \\
\text { Al-Ana'ām (The Cattle) } \\
\text { Al-Ahzab (The Confederates) } \\
\text { An-Nazia'āt ( The Pluckers ) } \\
\text { Al-Fajr (The Dawn) }\end{array}$ & $\begin{array}{c}57 \\
6 \\
8 \\
89 \\
43 \\
54 \\
79,164 \\
37 \\
6 \\
23\end{array}$ \\
\hline شبه اشتقاق & $\begin{array}{c}\text { An-Nisā (The Women) } \\
\text { AL-Baqara (The Cow) } \\
\text { Al-Tawba (Repentance) } \\
\text { Al-šuarā (THE POETS) } \\
\text { Yūsuf (Joseph) } \\
\text { Al-Jinn (The Jinn) } \\
\text { Al-Inšiqāq (The Rending) }\end{array}$ & $\begin{array}{c}11 \\
44 \\
38 \\
168 \\
84 \\
10 \\
17 \text { and } 18\end{array}$ \\
\hline مستوى & $\begin{array}{c}\text { Yā-Sīn (Ya-Seen) } \\
\text { Al-Anbīyā' (The Prophets) } \\
\text { Al-Muddathir (The Shrouded) }\end{array}$ & $\begin{array}{c}40 \\
33 \\
3\end{array}$ \\
\hline
\end{tabular}

